\title{
SHEAR RESISTANCE OF REINFORCED CONCRETE BEAMS IN DEPENDENCE ON CONCRETE STRENGTH IN COMPRESSIVE STRUTS
}

\author{
Davor Grandić, Paulo Šćulac, Ivana Štimac Grandić
}

Original scientific paper

In the current European Code EN 1992-1-1 a truss model with variable inclination angle of concrete compressive struts with a quite wide range of inclination angle, from $21,8^{\circ}$ to $45^{\circ}$, is intended for use for shear design of reinforced concrete beams. However, some researches and recommendations indicate special attention when choosing the lower bound of inclination angle of the concrete compressive struts, due to the reduced compressive strength of cracked concrete. This work reviews theoretical background and shear design methods of reinforced concrete beams. Relation of the shear resistance to crushing of the compressive struts as a function of their inclination angle has been investigated through a parametric study, where three different approaches have been used in order to limit stresses in the compressive struts. Based on the comparison of results from the analysis a recommendation for shear resistance calculation of reinforced concrete beams in dependence on concrete strength in compressive struts of the truss model is given.

Keywords: compressive struts inclination angle; shear; truss model

Nosivost armiranobetonskih greda na poprečne sile po kriteriju čvrstoće betonskih tlačnih štapova

Izvorni znanstveni članak U aktualnoj europskoj normi EN 1992-1-1 za dimenzioniranje armiranobetonskih greda na poprečne sile predviđa se uporaba rešetkastog modela sa slobodnim odabirom nagiba betonskih tlačnih ispunskih štapova u širokim granicama, to jest od $21,8^{\circ}$ do $45^{\circ}$ prema osi grede. Međutim, postoje istraživanja i prijedlozi koji upućuju na oprez kod odabira donje granice nagiba ispunskih tlačnih štapova s obzirom na umanjenje tlačne čvrstoće raspucanog betona u hrptu armiranobetonskih elemenata izloženih poprečnim silama. U radu je dan pregled teorijskih postavki i metoda proračuna armiranobetonskih elemenata na poprečne sile. Provedena je parametarska analiza nosivosti na poprečne sile pri drobljenju tlačnih štapova kao funkcije njihovog nagiba. Pri tom su korištena su tri različita pristupa za ograničenje naprezanja u tlačnim štapovima. Na temelju provedene analize i usporedbe rezultata u radu je dan prijedlog za određivanje nosivosti armiranobetonskih greda na poprečne sile po kriteriju čvrstoće betona ispunskih tlačnih štapova rešetkastog modela.

Ključne riječi: kut nagiba tlačnih štapova; posmik; rešetkasti proračunski model

\section{Introduction}

Since the early days of reinforced concrete the socalled classical truss analogy developed by Ritter and Mörsch (Ritter 1899, Mörsch 1908) [1, 2] was proposed for shear design of reinforced concrete members (Fig. 1). The truss analogy is based on a truss model with parallel chords and web members connected by means of pin joints, where the concrete compressive struts are inclined at $45^{\circ}$ with respect to the longitudinal axis of the beam while the shear reinforcement represents the tensile web members.

Ritter (1899)

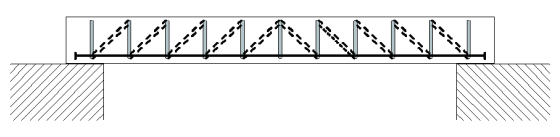

Mörsch (1908)

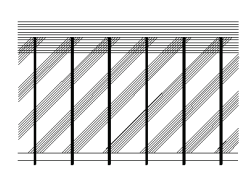

a) Truss model

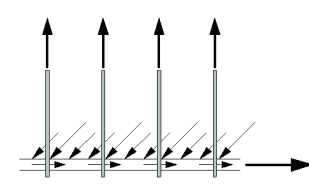

b) Stirrup forces
Figure 1 Ritter's and Mörsch's original truss model

According to Zilch and Zehetmaier [2], when the shear reinforcement (stirrups) is placed closely to each other the simple truss becomes a statically indeterminate truss (Fig. 2b). Generally, the truss model may be considered as a statically determinate simple truss composed of resultant forces from parallel tension and compression stress fields with pinned joints (Fig. 2c).

a)

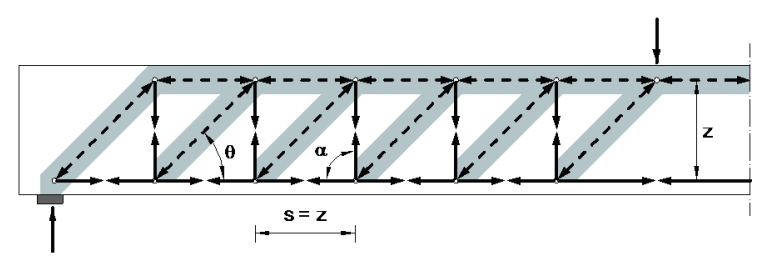

b)

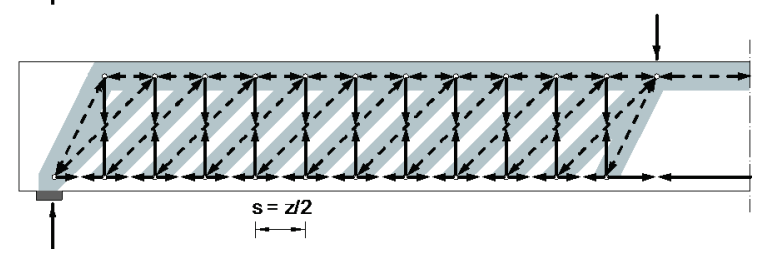

c)

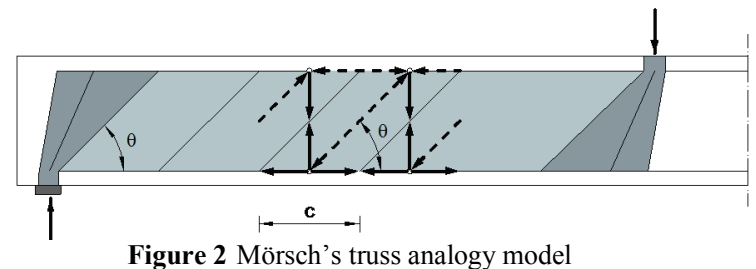

Figure 2 Mörsch's truss analogy model

However, experimental studies carried out in Stuttgart during 1960-s [3] indicated that the stresses in shear reinforcement were considerably lower than those predicted by the truss analogy model. This is due to the contribution of other components to the shear carrying mechanism, among which the most significant are: contribution of concrete in the compression zone, aggregate interlock along inclined cracks and dowel action of the longitudinal reinforcement crossing the 
crack [1]. Also, the actual inclination of the shear cracks is often less than $45^{\circ}$ [3], what greatly depends on the shape of the member cross-section. This means that Mörsch's truss analogy underestimates the shear resistance of a member (Fig. 3).
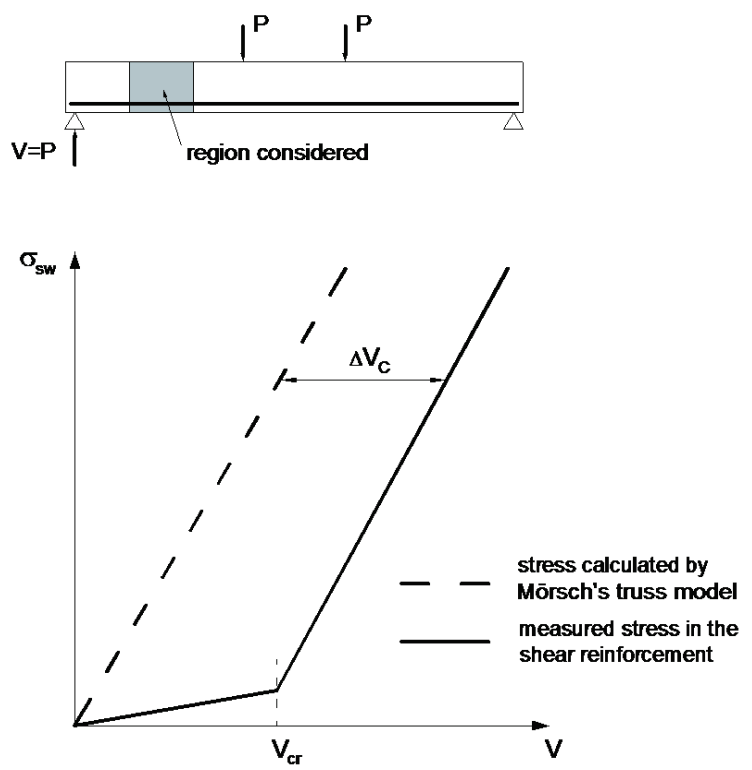

Figure 3 Characteristic relationship between stress in shear reinforcement and shear force

Reinforced concrete beams subjected to shear have been traditionally designed using one of the two following methods:

1) truss model with $45^{\circ}$ compressive strut inclination angle and directly included the so-called concrete contribution (correction term) $\Delta V_{\mathrm{c}}$ (Fig. 3)

This kind of truss model was implemented in European Prestandard ENV 1992-1-1 [4], ACI 318 Building Code [5] and in some National Codes mentioned in [6]. This method is the so-called standard method according to $[4,14]$. It is also referred to as the extended Mörsch analogy (EMA) [1, 2].

2) truss model with variable compressive strut inclination angle lower than $45^{\circ}$

This method, based on plasticity theory, is accepted in the current European Codes [7, 8].

The truss model with variable compressive strut inclination angle is a logical extension of the application of the strut and tie models, which have already been included in various Codes [5, 7, 8, 9], on standard structural members. This method fits in the consistent approach of structural analysis, design and detailing of reinforced concrete structures and members, such as beams, columns, plates, deep beams, corbels, beamcolumn joints, special details etc., subjected to bending, shear and axial forces, torsion or punching shear [10].

In the following of this paper a brief overview of the truss model with variable compressive strut inclination angle is presented, and various limitations of the inclination angles are discussed. On the basis of a parametric study, a recommendation for limitation of the stresses in compressive struts is given in dependence on the inclination angle chosen according to the shear resistance criterion of the member.

\section{Basic features of the truss model with variable compressive struts inclination angle}

A truss model of a reinforced concrete beam section is shown in Fig. 4. The notations in Fig. 4 are as follows: $V_{\mathrm{Ed}}, N_{\mathrm{Ed}}, M_{\mathrm{Eds}}$ - design value of the cross-sectional forces: shear force, axial force and bending moment with respect to the centroid of the tensile reinforcement, respectively,

$F_{\text {swd }}$ and $F_{\text {cwd }}$ - tensile and compressive web member forces,

$F_{\text {sd }}$ and $F_{\text {cd }}-$ tensile and compressive chord forces,

$\theta$ - angle of inclination of the concrete compressive strut with respect to the longitudinal beam axis,

$\alpha$ - angle of inclination of the tensile web member (shear reinforcement) with respect to the longitudinal beam axis.
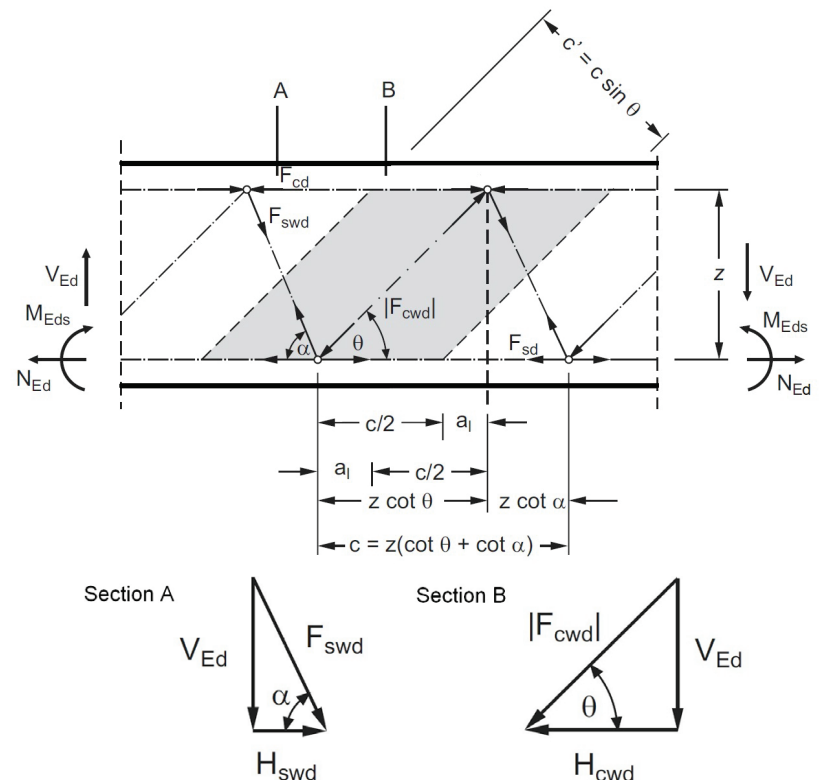

Figure 4 Forces of the truss model [2]

By analysing the truss model in Fig. 4 the design stresses in the inclined concrete compressive struts $\sigma_{\mathrm{cwd}}$ (hereinafter referred to as compressive struts) and design stresses in the shear reinforcement $\sigma_{\text {swd }}$ may be determined. Assuming that the compressive struts represent the resultant of the inclined compressive stress fields, we get:

$\left|\sigma_{\mathrm{cwd}}\right|=\frac{V_{\mathrm{Ed}}\left(1+\cot ^{2} \theta\right)}{b_{\mathrm{w}} \cdot z(\cot \theta+\cot \alpha)}$,

$\sigma_{\mathrm{swd}}=\frac{V_{\mathrm{Ed}}}{a_{\mathrm{sw}} \cdot z \cdot \sin \alpha(\cot \theta+\cot \alpha)}$,

where:

$b_{\mathrm{w}}-$ minimum beam web width,

$z$ - lever arm (distance between the centroids of compressive and tensile chords),

$a_{\mathrm{sw}}=A_{\mathrm{sw}} / s-$ cross-sectional area of the shear reinforcement within longitudinal spacing $s$.

Compressive stress in concrete $\sigma_{\text {cwd }}$ in Eq. (1) as well as the force $F_{\text {cwd }}$ in the compressive strut in Fig. 4 should be taken with a negative sign $\left(\sigma_{\text {cwd }}<0\right.$ and $\left.F_{\text {cwd }}<0\right)$. Actually, the stress in concrete struts in Eq. (1) and the 
stress in shear reinforcement in Eq. (2) are defined as the web member forces $F_{\text {cwd }}$ and $F_{\text {swd }}$ distributed per area with width $b_{\mathrm{w}}$ and length $c^{\prime}$ and $c$, respectively.

The longitudinal reinforcement must be able to resist the additional force $\Delta F_{\text {sd }}$ that occurs in the tensile chord due to shear, which can be determined on the basis of the truss model from Fig. 4:

$$
\Delta F_{\mathrm{sd}}=\frac{H_{\mathrm{cwd}}-H_{\mathrm{swd}}}{2}=\frac{V_{\mathrm{Ed}}}{2}(\cot \theta-\cot \alpha) .
$$

Replacing $\sigma_{\text {cwd }}$ in Eq. (1) with effective compressive strength of concrete cracked in shear $f_{\text {cwd }}$ and $\sigma_{\text {swd }}$ in Eq. (2) with design yield strength of shear reinforcement $f_{y \mathrm{wd}}$, along with $V_{\mathrm{Ed}}=V_{\mathrm{Rd} \text {,max }}$ and $V_{\mathrm{Ed}}=V_{\mathrm{Rd}, \mathrm{s}}$ we obtain the maximum design shear resistance of the member limited by crushing of the compressive struts $V_{\mathrm{Rd} \text {,max }}$ :

$$
V_{\mathrm{Rd}, \text { max }}=b_{\mathrm{w}} \cdot z \cdot f_{\mathrm{cwd}} \cdot \frac{\cot \theta+\cot \alpha}{1+\cot ^{2} \theta},
$$

and design shear resistance of the member limited by yielding of the tensile web members (shear reinforcement) $V_{\mathrm{Rd}, \mathrm{s}}$ :

$$
V_{\mathrm{Rd}, \mathrm{s}}=\frac{A_{\mathrm{sw}}}{s} \cdot z \cdot f_{y \mathrm{wd}} \cdot(\cot \theta+\cot \alpha) \cdot \sin \alpha .
$$

Term $V_{\text {Rd,max }}$ also denotes the maximum shear capacity which a member can sustain for a chosen angle $\theta$, provided that the shear force is carried by an appropriate shear reinforcement i.e. $V_{\mathrm{Rd}, \max }=V_{\mathrm{Rd}, \mathrm{s}}$ and that an additional longitudinal tensile reinforcement to resist $\Delta F_{\text {sd }}$ is provided.

From the analysis of the truss model in Fig. 4 it can be noticed that there are three equilibrium equations $(1,2$ and 3 ) but four unknowns: concrete stress $\sigma_{\text {cwd }}$, additional tensile force in longitudinal reinforcement $\Delta F_{\text {sd }}$, stress in the shear reinforcement $\sigma_{s w d}$ and inclination angle of the compressive struts $\theta$. Since there are only three equilibrium equations and four unknowns Mörsch concluded that it is mathematically impossible to determine the inclination angle $\theta$ [1].

In 1964, Kupfer used minimum strain energy principle to determine the angle $\theta$, while assuming linearelastic behaviour of both the reinforcing steel and cracked concrete [1]. In order to ensure that the strain energy of the bearing system has a minimum value, the stiffer the member the more load it must attract. Since in a typical reinforced concrete beam the longitudinal reinforcement is much stiffer than the shear reinforcement (stirrups), due to minimum strain energy principle the inclination angle $\theta$ must be lower than $45^{\circ}$.

In the truss analogy model (Mörsch-Ritter) the shear failure of a beam is governed by Eq. (2) assuming the shear reinforcement yields $\left(\sigma_{\mathrm{s}}=f_{y \mathrm{~d}}\right)$ and that the compressive strut inclination angle equals $45^{\circ}$.

Instead of assuming that $\theta$ equals $45^{\circ}$, we can assume the compressive strut stress equal to the effective compressive strength of cracked concrete $f_{\text {cwd }}$ along with the amount and yield strength of the shear reinforcement, in order to determine the shear resistance $\left(V_{\mathrm{Rd}, \mathrm{s}}=V_{\mathrm{Rd}, \max }\right)$ and inclination angle $\theta$ solving equations (1) and (2). As an alternative, both, the yielding of shear and longitudinal reinforcement may be assumed, and inclination angle $\theta$ and shear resistance $\left(V_{\mathrm{Ed}}=V_{\mathrm{Rd}, \mathrm{s}}\right)$ may be obtained through Eqs. (2) and (3). In addition, it still needs to be checked that the concrete stress does not exceed the effective compressive concrete strength $\left(\left|\sigma_{\text {cwd }}\right| \leq f_{\text {cwd }}\right)$, meaning that $V_{\mathrm{Rd}, \mathrm{s}} \leq V_{\mathrm{Rd} \text {,max }}$, and that there will be no crushing of the compressive struts. This type of failure mechanisms can be only achieved through proper redistribution of internal forces between concrete compressive struts and tensile reinforcement, which is based on plasticity theory $[10,11]$.

\section{Limitation of the compressive struts angle}

Structural analysis of members containing shear reinforcement using the truss model with variable inclination angle of compressive struts is based on the lower bound theorem (static theorem) of the theory of plasticity. According to lower bound theorem, each load satisfying a statically admissible stress field in which the yield strength of reinforcement and/or concrete compressive strength are not exceeded anywhere lies below the collapse load. A statically admissible stress field is every field in which the equilibrium conditions are satisfied. Hence, the ultimate shear resistance may be determined choosing an almost arbitrary inclination angle $\theta$ of the concrete compressive struts. This method, based on plasticity theory, implies that the element has sufficient ductility in order to ensure proper redistribution of internal forces within member what is possible due to plastic behaviour of the steel reinforcement.

Plasticity theory implies that the material has the ability to deform in a plastic manner. However, since concrete permits only limited plastic deformations, the range of the compressive strut inclination angle should be limited. For low inclination angle $\theta$ a large elongation of the shear reinforcement is required which in turn widens the inclined cracks and reduces the resistance of the inclined compressive struts $[10,12,13]$. At the same time, wider cracks may lead to a reduction of durability. Therefore, the lower bound value of the compressive strut inclination angle should be limited. In Tab. 1 a brief overview of various recommended values for compressive strut inclination angle $\theta$ to be used for shear design of reinforced concrete beams using the variable angle truss model is given.

Limitation of the lower bound of the inclination angle $\theta$ according to German Codes DIN 1045-1 and DIN EN 1992-1-1/NA is based on a truss model with crack friction [12], where the principal shear carrying mechanism is due to aggregate interlock (Fig. 5).

The notations in Fig. 5 are as follows: $T_{\text {crd }}$ and $N_{\text {crd }}$ are tangential and normal forces, respectively, acting at an inclined crack due to principal tensile stresses, and $\beta_{\mathrm{r}}$ is the inclined crack angle.

If there were no aggregate interlock along the crack faces, the compressive strut inclination angle would be equal to the crack angle, ie. $\theta=\beta_{\mathrm{r}}$. Since there actually occurs a shear transfer across the crack due to aggregate 
interlock the resultant inclined compressive stress field (compressive struts) will cross the cracks at a shallower angle $\left(\theta<\beta_{\mathrm{r}}\right)$. In the following only the vertical shear reinforcement $\left(\alpha=90^{\circ}\right)$ will be considered.

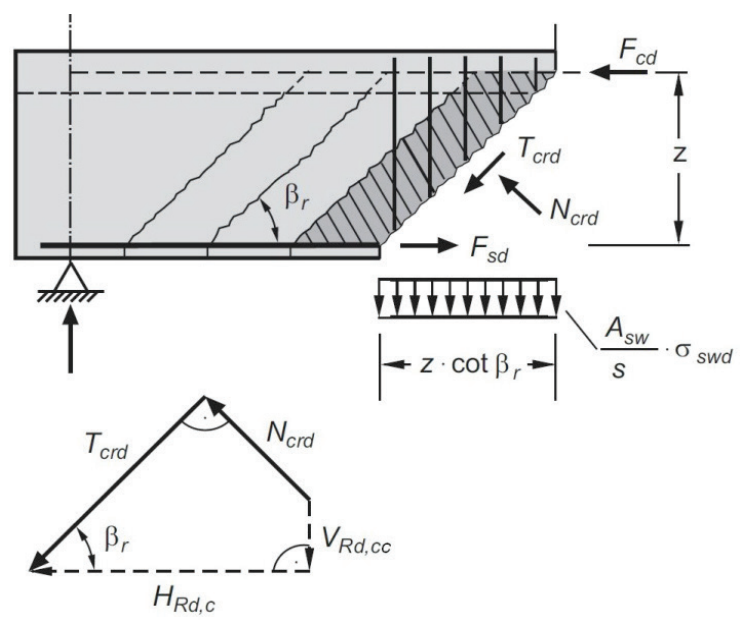

Figure 5 Free-body diagram of the end support region cut out at an inclined crack [2]

Vertical component of the resultant force at an inclined crack $V_{\mathrm{Rd}, \mathrm{cc}}$ (Fig. 5) represents the concrete contribution of the shear resistance of the truss model with crack friction. According to this model, shear resistance of a beam sustained by the yielding of the shear reinforcement may be derived from free-body diagram analysis in Fig. 5 (for $\sigma_{\mathrm{swd}}=f_{\mathrm{ywd}}$ ):
$V_{\mathrm{Rd}, \mathrm{s}}=a_{\mathrm{sw}} f_{y w d} z \cot \beta_{\mathrm{r}}+V_{\mathrm{Rd}, \mathrm{cc}}$.

It can be noticed that Eq. (6) has the same form as obtained using the extended Mörsch analogy (Fig. 3) for $\theta$ $=\beta_{\mathrm{r}}=45^{\circ}$, since it includes the shear reinforcement contribution (determined for $\theta=\beta_{\mathrm{r}}$ ) and the concrete contribution.

According to German Codes [8, 16] and research [12] $V_{\mathrm{Rd}, \mathrm{cc}}$ may be determined using the following empirical expression:

$V_{\mathrm{Rd}, \mathrm{cc}}=\left[c_{j} \cdot 0,48 \eta_{1} f_{\mathrm{ck}}^{1 / 3} \cdot\left(1+1,2 \cdot \frac{\sigma_{\mathrm{cd}}}{f_{\mathrm{cd}}}\right)\right] \cdot b_{\mathrm{w}} z$,

where:

$c_{j}=0,50$

$\eta_{1}$ - correction factor for lightweight concrete $\left(\eta_{1}=1\right.$ for normal weight concrete),

$f_{\mathrm{ck}}-$ characteristic compressive cylinder strength of concrete (in $\mathrm{MPa}$ ),

$\sigma_{\mathrm{cd}}-$ design value of normal stress at the centroid of the reinforced concrete member cross-section (negative for compression),

$f_{\text {cd }}-$ design value of concrete compressive strength (in $\mathrm{MPa}$,

$b_{\mathrm{w}}-$ minimum member cross-section width.

Table 1 Proposed values for compressive strut inclination angle $\theta$

\begin{tabular}{|c|c|c|c|}
\hline Proposed by & Cotangent $\theta$ & Angle $\theta$ & Note \\
\hline Thürliman et al. [11] & $1,0 \leq \cot \theta \leq 2,5$ & $45^{\circ} \geq \theta \geq 21,8^{\circ}$ & - \\
\hline MC 78 [14] & $0,6 \leq \cot \theta \leq 1,67$ & $59^{\circ} \geq \theta \geq 31^{\circ}$ & - \\
\hline ÖNORM EN1992-1-1/NA [15] & $0,4 \leq \cot \theta \leq 2,5$ & $68^{\circ} \geq \theta \geq 21,8^{\circ}$ & $\begin{array}{c}\text { for beams with constant longitudinal } \\
\text { reinforcement } \\
\text { for beams with curtailed longitudinal } \\
\text { reinforcement }\end{array}$ \\
\hline ENV 1992-1-1 [4] & $0,5 \leq \cot \theta \leq 2,0$ & $63^{\circ} \geq \theta \geq 27^{\circ}$ & - \\
\hline MC 90 [9] & $1,0 \leq \cot \theta \leq 3,0$ & $45^{\circ} \geq \theta \geq 18,4^{\circ}$ & $\begin{array}{c}\text { - } \\
\text { DIN 1045-1 [8] }\end{array}$ \\
\hline EN 1992-1-1/ NA [16] & $0,58 \leq \cot \theta \leq 3,0$ & $59,9^{\circ} \geq \theta \geq 18,4^{\circ}$ & $\begin{array}{c}\text { this are the limit values for } \theta, \text { more accurate } \\
\text { values depending on the shear force is given } \\
\text { by Eq. (10) }\end{array}$ \\
\hline
\end{tabular}

Design value of concrete compressive strength $f_{\mathrm{cd}}$ is defined as:

$$
f_{\mathrm{cd}}=\alpha_{\mathrm{cc}} f_{\mathrm{ck}} / \gamma_{\mathrm{C}}
$$

where:

$\alpha_{\mathrm{cc}}$ is the coefficient taking account of unfavourable long term effects and effects resulting from the way the load is applied, and $\gamma_{\mathrm{C}}$ is the partial safety factor for concrete [7, $8]$. According to $[8,16]$ the proposed value for $\alpha_{\mathrm{cc}}$ is 0,85 . Combining Eq. (5) and Eq. (6) for $\alpha=90^{\circ}$ gives:

$\cot \theta=\cot \beta_{\mathrm{r}}+\frac{V_{\mathrm{Rd}, \mathrm{cc}}}{a_{\mathrm{sw}} f_{y \mathrm{wd}} z}$.
Also note that the equilibrium equation $V_{\mathrm{Ed}}=V_{\mathrm{Rd}, \mathrm{s}}$ is applied:

$$
\cot \theta=\cot \beta_{\mathrm{r}}+\frac{V_{\mathrm{Rd}, \mathrm{cc}}}{\frac{\left(V_{\mathrm{Rd}, \mathrm{s}}-V_{\mathrm{Rd}, \mathrm{cc}}\right)}{\cot \beta_{\mathrm{r}}}}=\frac{\cot \beta_{r}}{1-\frac{V_{\mathrm{Rd}, \mathrm{cc}}}{V_{\mathrm{Ed}}}} .
$$

The crack inclination angle depends on the concrete tensile strength and on normal stress in the concrete. German Codes [8, 16] and literature [2] propose a linearized term expressed through the design value of concrete compressive strength $f_{\text {cd }}$ :

$\cot \beta_{\mathrm{r}}=1,2-1,4 \frac{\sigma_{\mathrm{cd}}}{f_{\mathrm{cd}}}$ 
Finally, the condition for compressive strut inclination angle proposed by German Codes $[8,16]$ is:

$$
0,58 \leq \cot \theta \leq \min \left\{\frac{1,2-1,4 \sigma_{\mathrm{cd}} / f_{\mathrm{cd}}}{1-V_{\mathrm{Rd}, \mathrm{cc}} / V_{\mathrm{Ed}}} ; 3,0\right\} \text {. }
$$

For reinforced concrete beams without normal stresses, using Eq. (11) it can be determined that $\cot \beta_{\mathrm{r}}=$ 1,2 , i.e. $\beta_{\mathrm{r}}=39,8^{\circ}$.

\section{Effective concrete compressive strength}

Variable angle truss method utilises effective concrete compressive strength which is lower than the standard concrete compressive cylinder strength. In this way the cracking of concrete and stress field distribution across initial cracks in the concrete web is taken into account. For example, Marti [17] suggests $0,6 f^{\prime}$, where $f_{\mathrm{c}}^{\prime}$ is the nominal concrete compressive strength according to ACI 318 [5].

\subsection{Approach according to EN 1992-1-1}

According to EN 1992-1-1 the effective design value of concrete compressive strength is obtained by reduction of the design compressive strength $f_{\mathrm{cd}}$ :

$$
f_{\mathrm{cwd}}=\alpha_{\mathrm{cw}} v_{1} f_{\mathrm{cd}}
$$

where $\alpha_{\mathrm{cw}}$ is a coefficient that takes into account the effect of normal stress in the compression chord, $\alpha_{\mathrm{cw}}=$ 1,0 for non-prestressed members, $v_{1}$ is the strength reduction factor for concrete cracked in shear:

$$
v_{1}=0,6\left(1-\frac{f_{\mathrm{ck}}}{250}\right), \text { with } f_{\mathrm{ck}} \text { in } \mathrm{MPa} \text {, }
$$

and $f_{\text {cd }}$ is the design value of concrete compressive strength according to Eq. (8).

\subsection{Approach according to DIN 1045-1 and DIN EN 1992-1-1/NA}

German Codes [8, 16] define the effective design value of concrete compressive strength of normal weight concrete for shear design as:

$$
f_{\text {cwd }}=0,75 v_{2} f_{\text {cd }}
$$

where $v_{2}$ is a coefficient which depends on characteristic compressive cylinder strength:

$v_{2}=\min \left\{1,1-\frac{f_{\mathrm{ck}}}{500} ; 1,0\right\}$, with $f_{\mathrm{ck}}$ in $\mathrm{MPa}$,

and $f_{\mathrm{cd}}$ is the design value of concrete compressive strength according to Eq. (8).

Strength $f_{\text {cwd }}$ according to Eq. (15) is the maximum value which the effective concrete strength may take.
Further reduction of the compressive strength is not intended for use, since the ability of transferring concrete stresses across inclined cracks at a certain angle $\theta$ is explicitly taken into account through concrete contribution $V_{\mathrm{Rd}, \mathrm{cc}}$ in compressive strut range angle limitations [12].

\subsection{Approach according to Canadian researches}

According to Canadian researches [13, 18-20], which are implemented in CSA 2004 Standard [17], effective compressive strength of cracked concrete in the web (compressive struts) $f_{\mathrm{c} 2 \text {, max }}$ is obtained as reduction of nominal concrete compressive strength $f_{\mathrm{c}}^{\prime}$ through softening parameter $\beta$ :

$f_{\mathrm{c} 2, \max }=\beta \cdot f_{\mathrm{c}}^{\prime}$

Softening parameter $\beta$ may be determined as:

$$
\begin{aligned}
& \beta=\min \left\{\frac{1}{0,80+170 \varepsilon_{1}} ; 1,0\right\}, \\
& \varepsilon_{1}=\varepsilon_{x}+\left(\varepsilon_{x}-\varepsilon_{2}\right) \cot ^{2} \theta,
\end{aligned}
$$

where:

$\varepsilon_{1}$ - the average principal tensile strain in web,

$\varepsilon_{x}$ - longitudinal strain in web calculated at the mid-depth of the effective web width (at $z / 2, z$ in Fig. 4),

$\varepsilon_{2}$ - principal compressive strain (in the direction of the compressive strut), negative value,

$\theta$ - stress field (strut) inclination angle with respect to the tensile chord.

Expression (19) results from the stress field theory [1, $21]$ in which the equilibrium and compatibility conditions of web cracked in shear in reinforced concrete members are included. The advantage of this approach lies in the following: greater principal tensile strain causes wider cracks, which in turn reduce aggregate interlock contribution and cause smaller effective concrete compressive strength $f_{\mathrm{c} 2 \text {, max }}$

The softening parameter $\beta$ in Eq. (18) has been derived on the basis of a large number of reinforced concrete panel tests loaded in shear [13, 12, 20]. Majority of the tests have been carried out on concrete whose strengths were smaller than approximately $40 \mathrm{MPa}$. For members with higher concrete compressive strengths the softening parameter $\beta$ may be determined as [22]:

$\beta=\min \left\{\frac{1}{1+K_{\mathrm{c}} K_{\mathrm{f}}} ; 1,0\right\}$,

where $K_{\mathrm{c}}$ represents the effect of the transverse cracking and straining, while $K_{\mathrm{f}}$ represents the dependence on the concrete strength $f_{\mathrm{c}}^{\prime}$.

In this work the model with both the peak stress and the strain at which the peak stress occurs reduced (socalled "strength and strain-softening model") is used (Fig. 6). This model was chosen since for concrete with greater 
compressive strength gives greater reduction, what is in good accordance with most researches [6].

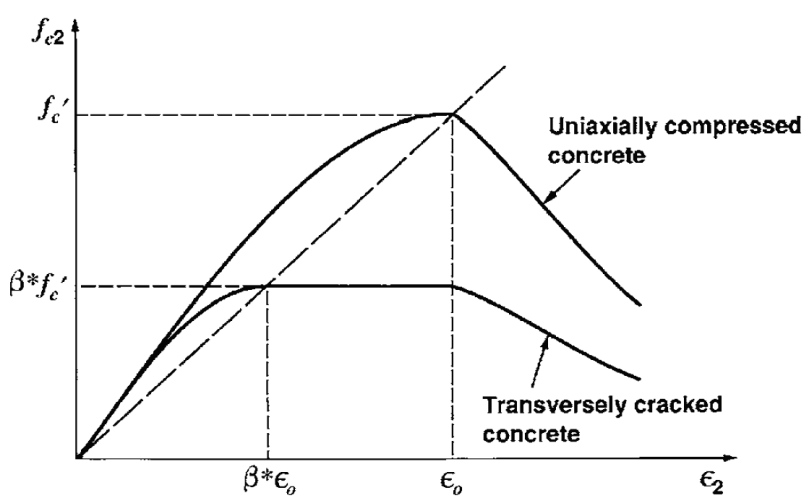

Figure 6 Stress-strain relationship for cracked concrete in compression (model A in [22])

Transverse cracking factor $K_{\mathrm{c}}$ according to [22] may be determined as:

$K_{\mathrm{c}}=0,35\left(\frac{-\varepsilon_{1}}{\varepsilon_{2}}-0,28\right)^{0,80}$

The strength-influence factor $K_{\mathrm{f}}$ is defined as:

$K_{\mathrm{f}}=\max \left\{0,1825 \sqrt{f_{\mathrm{c}}^{\prime}} ; 1,0\right\}$,

where $f_{\mathrm{c}}^{\prime}$ is the nominal compressive cylinder strength of concrete in $\mathrm{MPa}$.

\section{Parametric study}

A parametric study of normalised maximum design shear resistance in dependence on inclination angle $\theta$ has been conducted taking into account the three above presented approaches for stress limitation in the compressive struts (EN 1992-1-1, DIN 1045-1/DIN \& EN 1991-1-1/NA and Canadian researches).

\subsection{Normalised maximum design shear resistance}

In order to compare the previously described approaches with EN 1992-1-1, the maximum shear resistances $V_{\mathrm{Rd} \text { max }}$ are normalised according to the following expression:

$$
v_{\mathrm{Rd}, \max }=\frac{V_{\mathrm{Rd}, \max }}{b_{\mathrm{w}} z \alpha_{\mathrm{cw}} v_{1} f_{\mathrm{cd}}},
$$

where:

$v_{\mathrm{Rd}, \max }-$ normalised maximum design shear resistance,

$\alpha_{\mathrm{cw}} v_{1} f_{\mathrm{cd}}$ - effective design concrete compressive strength $\left(f_{\text {cwd }}\right)$ according to Eq. (12) for non-prestressed members, $f_{\text {cd }}$ may be determined using Eq. (8) with the recommended value of $\alpha_{\mathrm{cc}}=1,0$ according to EN 1992-11 [7].

This study is conducted for vertical shear reinforcement ie. stirrups $\left(\alpha=90^{\circ}\right)$ and for reinforced concrete non-prestressed beams subjected to bending moment and shear force $\left(\alpha_{\mathrm{cw}}=1,0\right)$.

\section{a) Approach according to EN 1992-1-1}

Normalised maximum design shear resistance may be determined using Eq. (4) and (23):

$$
v_{\mathrm{Rd}, \max }=\frac{b_{\mathrm{w}} z \alpha_{\mathrm{cw}} v_{1} f_{\mathrm{cd}} \frac{\cot \theta}{1+\cot ^{2} \theta}}{b_{\mathrm{w}} z \alpha_{\mathrm{cw}} v_{1} f_{\mathrm{cd}}}=\frac{1}{\cot \theta+\tan \theta} .
$$

\section{b) Approach according to DIN 1045-1 and DIN EN 1992-1-1/NA}

Maximum design shear resistance $V_{\mathrm{Rd} \text { max }}$ may be determined using Eq. (9), assuming at the same time crushing of the compressive struts and yielding of the shear reinforcement, i.e. $V_{\mathrm{Rd} \text {,max }}=V_{\mathrm{Rds}}=V_{\mathrm{Ed}}$. It should also meet the condition in Eq. (15), by using the appropriate $f_{\text {cwd }}$ in Eq. (4). Thus, the normalised maximum shear resistance follows as:

$$
v_{\mathrm{Rd}, \text { max }}=\min \left\{\begin{array}{l}
\frac{\frac{V_{\mathrm{Rd}, \mathrm{cc}}}{b_{\mathrm{w}} z} \cdot \frac{\cot \theta}{\cot \theta-\cot \beta_{r}}}{\alpha_{c w} v_{1} f_{c d}} \\
\frac{\left(0,85 \cdot 075 v_{2} f_{\mathrm{cd}}\right) \frac{1}{\cot \theta+\tan \theta}}{\alpha_{\mathrm{cw}} v_{1} f_{\mathrm{cd}}}
\end{array}\right\},
$$

where $f_{\text {cd }}$ is in $\mathrm{MPa}$.

In the above Eq. (25) $f_{\text {cd }}$ is multiplied with 0,85 whereby the difference between recommended value according to EN 1992-1-1 $\left(\alpha_{\mathrm{cc}}=1,0\right)$ and prescribed by German National Annex $\left(\alpha_{\mathrm{cc}}=0,85\right)$ is taken into account [16]. After some arranging of Eq. (25) and using $\eta_{1}=1$ for normal weight concrete according to (7) yields:

$$
v_{\mathrm{Rd}, \max }=\min \left\{\begin{array}{l}
\frac{0,24 \gamma_{\mathrm{C}} f_{\mathrm{ck}}^{-\frac{2}{3}}}{\alpha_{\mathrm{cw}} v_{1}} \cdot \frac{\cot \theta}{\cot \theta-\cot \beta_{\mathrm{r}}} \\
\frac{0,638 v_{2}}{\alpha_{\mathrm{cw}} \nu_{1}} \cdot \frac{1}{\cot \theta+\tan \theta}
\end{array}\right\},
$$

where $f_{\text {ck }}$ is in MPa.

In case of reinforced concrete beams without axial force considered in this paper $\cot \beta_{\mathrm{r}}=1,2$.

\section{c) Approach according to Canadian researches}

In order to compare this approach with approach according to EN 1992-1-1 (a), strength softening parameter $\beta$ is instead on nominal concrete compressive strength $f_{\mathrm{c}}^{\prime}$ applied on the design concrete compressive strength $f_{\text {cd }}$. Hence, the design effective concrete compressive web is obtained as:

$$
f_{\mathrm{cwd}}=\beta \cdot f_{\mathrm{cd}},
$$


where:

$\beta$ - concrete strength softening parameter,

$f_{\text {cd }}$ - design concrete compressive strength defined through (8) for $\alpha_{\mathrm{cc}}=1,0$, assuming that $f_{\mathrm{c}}^{\prime} \approx f_{\mathrm{ck}}$.

Design compressive strength $f_{\text {cd }}$ is defined in accordance with EN 1992-1-1 reliability concept in which the partial factors are used both for materials and actions. Furthermore, we assume that the concrete strain in web $\varepsilon_{x}$ equals 0,001 , which is generally valid for reinforced concrete beams [12]. In addition, the principal compressive strain in concrete web $\varepsilon_{2}$ is assumed to be equal to the concrete compressive strain reaching the concrete compressive strength $\varepsilon_{\mathrm{c} 2}$. According to EN 1992$1-1, \quad \varepsilon_{\mathrm{c} 2}=-0,002$ for concrete whose characteristic compressive cylinder strength is less or equal to $50 \mathrm{MPa}$ (for high-strength concrete $\left|\varepsilon_{\mathrm{c} 2}\right|$ is greater than 0,002). Taking the compressive strain $\varepsilon_{\mathrm{c} 2}$ and appropriate concrete compressive strength along with yielding of the shear reinforcement we obtain the shear resistance satisfying the lower bound theorem of plasticity theory.
This means that in this case equilibrium equations according to stress-fields are the same as those obtained through variable strut inclination model $[1,6]$.

Maximum shear resistance $V_{\mathrm{Rd} \text {,max }}$ is determined through substitution of $f_{\text {cwd }}$ calculated according to Eq. (5) with $f_{\text {cwd }}$ calculated according to Eq. (27), which gives the normalised value:

$$
v_{\mathrm{Rd}, \max }=\frac{\beta}{\alpha_{\mathrm{cw}} v_{1}} \cdot \frac{1}{\cot \theta+\tan \theta} .
$$

\subsection{Results of the parametric study and discussion}

Parametric study was conducted through Eqs. (24), (26) and (28), in which the compressive struts inclination angle $\left(45^{\circ} \geq \theta \geq 21,8^{\circ}\right.$, inclination limitation according to EN 1992-1-1) and concrete compressive strengths have been varied. The results of the study are shown in Fig. 7 and Fig. 8.

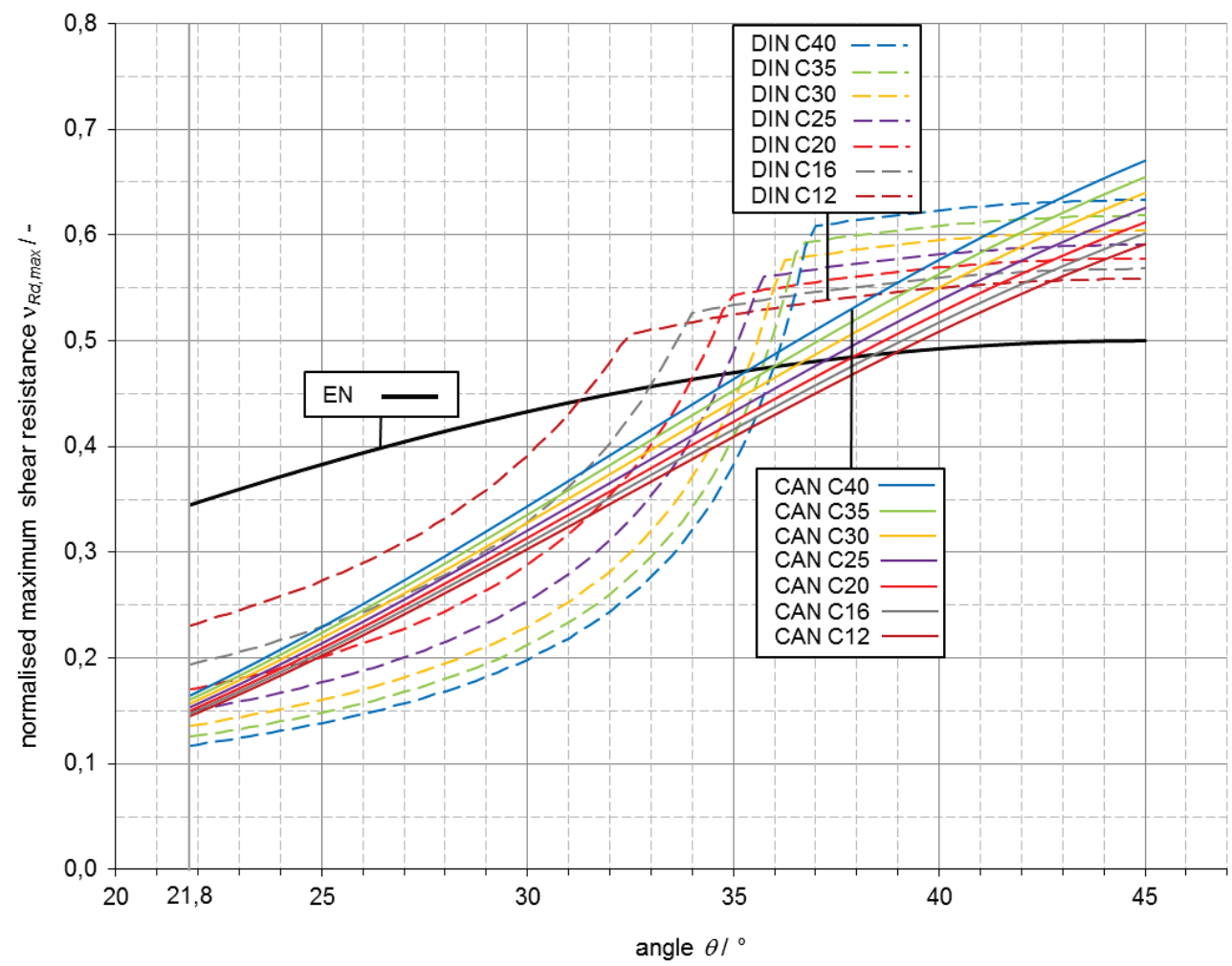

Figure 7 Relation between normalised maximum shear resistance $v_{\mathrm{Rd}, \max }$ and angle $\theta\left(\alpha=90^{\circ}, 12 \leq f_{\mathrm{ck}} \leq 40 \mathrm{MPa}\right)$

The curve labels are as follows:

a) approach according to EN 1992-1-1 $\rightarrow$ label EN

b) approach according to DIN EN 1992-1-1/NA and DIN $1045-1 \rightarrow$ label DIN

c) approach according to Canadian researches $\rightarrow$ label CAN.

Characteristic concrete compressive strength on diagrams is denoted as: letter $\mathrm{C}$ and number denoting the compressive cylinder strength $f_{\mathrm{ck}}$ in $\mathrm{MPa}$; for example, concrete $\mathrm{C} 20$ has characteristic concrete strength $f_{\mathrm{ck}}=20$ $\mathrm{MPa}$.

Presented charts may be used, not only for comparison of above presented approaches for stress limitation in compressive struts but also for shear design of reinforced concrete beams. The design procedure may be performed using the diagrams according to the following procedure:

1) using resistance requirements $V_{\mathrm{Rd} \text {,max }}$ can be equalized to $V_{\mathrm{Ed}}$ (the value of $V_{\mathrm{Ed}}$ is known in advance), then

2) from Eq. (23) $v_{\text {Rd,max }}$ may be calculated

3) depending on the concrete strength, for determined $v_{\mathrm{Rd}, \max }$ the inclination angle $\theta$ may be obtained from Fig. 7 or Fig. 8

4) using the obtained angle $\theta$ and meeting the condition $V_{\mathrm{Ed}}=V_{\mathrm{Rd}, \mathrm{s}}$, from Eq. (5), the required shear reinforcement $A_{\mathrm{sw}}$ may be determined. 
Using the above described procedure the shear resistance will be satisfied with both yielding of the reinforcement and reaching the resistance of the compressive struts, i.e.: $V_{\mathrm{Ed}}=V_{\mathrm{Rd}, \max }=V_{\mathrm{Rd}, \mathrm{s}}$. For $\alpha<90^{\circ}$ the normalised design shear resistance $v_{\mathrm{Rd} \text { max }}$ may be determined by multiplying values obtained for $\alpha=90^{\circ}$ (Fig. 7 and Fig. 8) with $(\cot \theta+\cot \alpha) / \cot \theta$.
Based on the comparison of the diagrams in Fig. 7 and Fig. 8 it may be noticed that each of the proposed approaches gives conservative values for $v_{\mathrm{Rd} \text {,max }}$, with respect to the other approaches, in different ranges of the compressive struts inclination angle $\theta$.

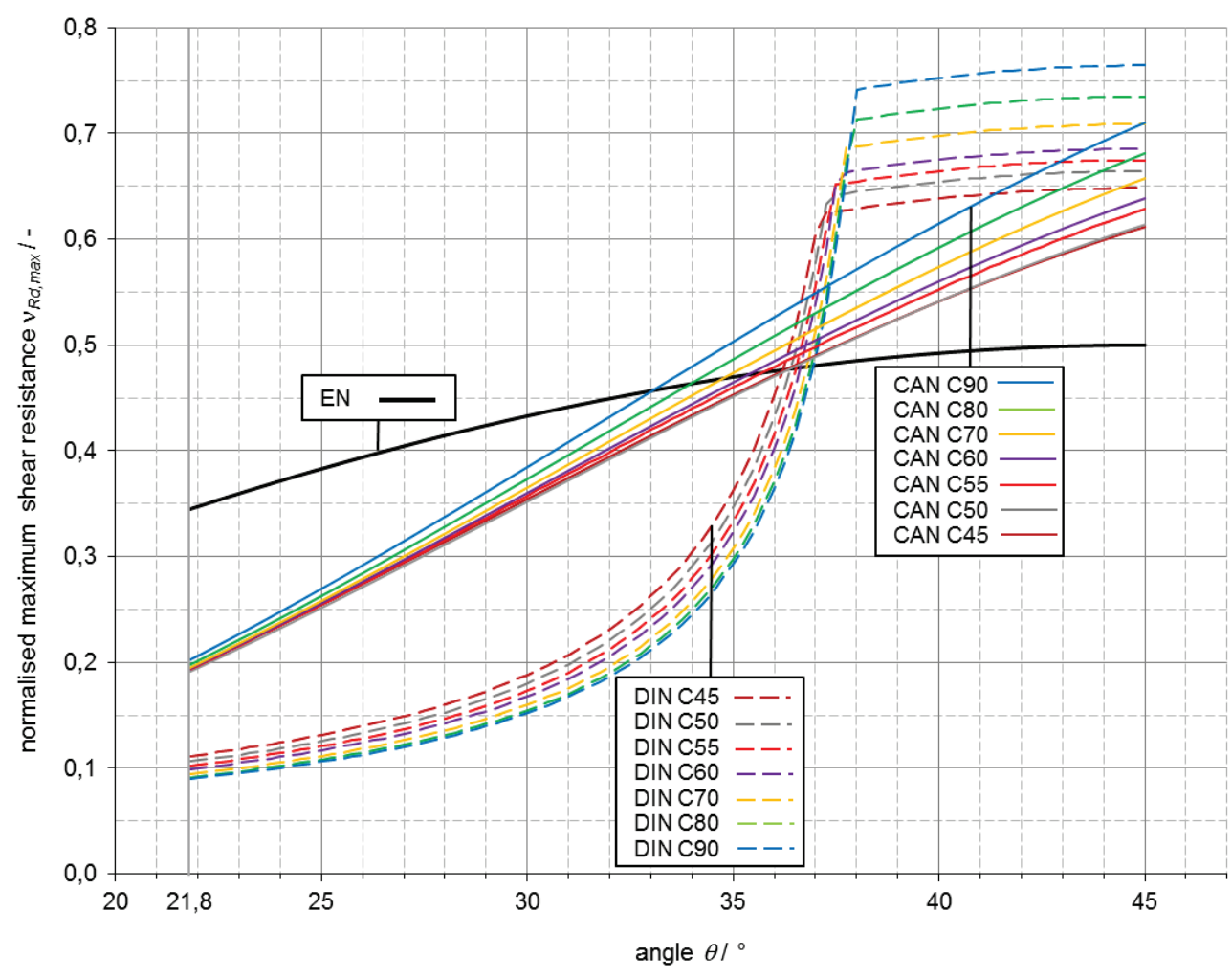

Figure 8 Relation between normalised maximum shear resistance $v_{\mathrm{Rd}, \max }$ and angle $\theta\left(\alpha=90^{\circ}, 45 \leq f_{\mathrm{ck}} \leq 90 \mathrm{MPa}\right)$

According to EN approach, for concrete classes with $f_{\text {ck }} \leq 40 \mathrm{MPa}$ in region where $\theta \geq 39^{\circ} v_{\mathrm{Rd} \text {,max }}$ takes minimum values, while in regions where $\theta \leq 31^{\circ} v_{\mathrm{Rd}, \max }$ takes maximum values (Fig. 7). For $\theta \leq 36^{\circ}$ and $f_{\text {ck }} \leq 40$ $\mathrm{MPa}$, depending on the concrete class, the smallest value of $v_{\mathrm{Rd} \text {,max }}$ is obtained for DIN or CAN approach while when the inclination angle $\theta$ is between $36^{\circ}$ and $39^{\circ}$ the most conservative is CAN approach. In regions where $21,8^{\circ} \leq \theta \leq 32^{\circ}$ there is a good agreement of $v_{\mathrm{Rd} \text {,max }}$ for $\mathrm{C} 16$ and $\mathrm{C} 20$ according to DIN and CAN approaches. This is in good accordance with results presented in [2], where a very good agreement is between DIN approach and modified compression field theory (Canadian researches) for concrete $\mathrm{C} 20$ and $\varepsilon_{x}=0,001$.

In case of high-strength concrete $\left(45 \leq f_{\mathrm{ck}} \leq 90 \mathrm{MPa}\right)$ in regions where $\theta \geq 37^{\circ}$ the smallest values for $v_{\mathrm{Rd} \text {,max }}$ are obtained according to EN approach while for $\theta \leq 33^{\circ}$ $v_{\mathrm{Rd} \text {,max }}$ takes maximum values according to EN approach (Fig. 8). In region $21,8^{\circ} \leq \theta \leq 36^{\circ}$ the most conservative values $v_{\mathrm{Rd} \text {,max }}$ are generally according to DIN approach.

Based on the analysis conducted it may be noticed that EN approach gives more conservative values for shear resistance with respect to crushing of the compressive struts for inclination angle $\theta \geq 39^{\circ}\left(f_{\mathrm{ck}} \leq 40\right.$ $\mathrm{MPa})$ i.e. for $\theta \geq 37^{\circ}\left(45 \leq f_{\mathrm{ck}} \leq 90\right)$. In this region considerably higher shear resistances are obtained according to CAN, and especially according to DIN than according to EN. On the other hand for $\theta<39^{\circ}\left(f_{\mathrm{ck}} \leq 40\right.$ $\mathrm{MPa})$ i.e. for $\theta<37^{\circ}\left(45 \leq f_{\mathrm{ck}} \leq 90\right)$ more conservative values are obtained according to CAN and DIN approach compared with EN approach. For high-strength concrete $\left(45 \leq f_{\mathrm{ck}} \leq 90\right)$ and angles $\theta<37^{\circ}$ the smallest shear resistances are obtained according to DIN.

German Codes and literature sources provide, as a simplification, recommended invariable values for $\cot \theta$ for shear resistance design of reinforced concrete beams according to the truss model. According to [23] for beams without axial compressive force a value of $\cot \theta=1,25(\theta$ $\left.=38,7^{\circ}\right)$ is proposed, while according to DIN 1045-1 [8] $\cot \theta=1,20\left(\theta=39,8^{\circ}\right)$ is recommended. Notice that this values match well with lower bound values of angle $\theta$ in which the EN approach becomes more conservative with respect to DIN and CAN approaches, i.e. for $\theta=39^{\circ}$, and $\theta=37^{\circ}$.

\section{Conclusion}

In this work a brief overview of the design methods and theoretical background for shear resistance design of reinforced concrete beams is given. A design method with variable compressive strut inclination angle, which is based on the truss model, has been discussed. According to this method a variable compressive strut inclination angle, in limited ranges, is allowed. A review of the 
limitations of the compressive strut inclination angle according to various recommendations and currently valid Codes is given. Expressions for normalised maximum shear resistance are derived according to three different approaches: Eurocode European Standard (EN), German Codes (DIN) and according to Canadian researches (CAN). A parametric study is conducted and some diagrams are made showing normalised maximum shear resistance in dependence on compressive strut inclination angle, which may also be used for structural design of reinforced concrete beams subjected to shear forces. A comparison of shear resistance design methods using different approaches is given. Some differences have been observed: according to each of them conservative values of shear resistance with respect to other two approaches are obtained, in different regions of compressive struts inclination angle.

Observed differences between approaches are the result of various researchers using different experimental results for design procedure validation. These differences may be also a result of different theoretical shear resistance models used. Some additional researches with the aim of achieving the same shear design reliability will be needed in the future. With respect to the actual use of the Eurocode 2 (EN 1992-1-1) a caution is needed when choosing the lower bound inclination angle of the truss model.

It may be concluded that using the invariable inclination angle values for simplified procedure of shear resistance design proposed by the German recommendations will always satisfy the safety requirements no matter the approach used.

As an alternative, the use of an upper and lower bound value of the inclination angle, as given in Eurocode 2, may be used, with the condition that shear resistance with respect to the crushing of the compressive struts is determined as the most conservative value according to approaches presented on diagrams in this work.

\section{Acknowledgment}

The authors thank the University of Rijeka for supporting the publication of this paper through grant No. 13.05.1.1.01.

\section{$7 \quad$ References}

[1] Collins, M. P.; Mitchell, D. Prestressed Concrete Structures. Response Publications, Montreal, Toronto, 1997.

[2] Zilch, K.; Zehetmaier, G. Bemessung im kostruktiven Betonbau. Springer-Verlag, Berlin Heidelberg, 2010. DOI: 10.1007/978-3-540-70638-0

[3] Leonhardt, F. Vorlesungen über Massivbau - Erster Teil, Springer-Verlag GmbH, 1973.

[4] ENV 1992-1-1: Eurocode 2 - Design of concrete structures - Part 1-1: General rules and rules for buildings. European committee for standardisation, Brussels, 1991.

[5] ACI 318-08: Building Code Requirements for Structural Concrete (ACI 318-08) and Commentary. American Concrete Institute, Farmington Hills, 2008.

[6] NISTIR 5870: Shear Design of High-Strength Concrete Beams: A Review of the State-of-the-Art. National Institute of Standards and Technology, Gaithersburg, USA, 1996.
[7] EN 1992-1-1: Eurocode 2 - Design of concrete structures Part 1-1: General rules and rules for buildings. European committee for standardisation, Brussels, 2004

[8] DIN 1045-1:2008: Tragwerke aus Beton, Stahlbeton und Spannbeton; Teil 2: Bemessung und Konstruktion, Betonkalender 2009. Ernst \& Sohn, Berlin, 2009. pp. 478584

[9] Comité Euro-International du Béton. CEB-FIP Model Code 1990, Design Code. Thomas Telford Services Ltd., London, 1993.

[10] Schlaich, J.; Schäfer, K.; Jennewein, M. Toward a Consistent Design of Structural Concrete. // PCI Journal. 32, 3(1987), pp. 74-150. DOI: 10.15554/pcij.05011987.74.150

[11] Thürlimann, B.; Marti P.; Pralong, J.; Ritz, P.; Zimmerli, B. Anwendung der Plastizitätstheorie auf Stahlbeton. Institut für Baustatik und Konstruktion, Eidgenössische Teshnische Hohschule Zürich, Zürich, 1983.

[12] Reineck, K. H. Hintergründe zur Querkraftbemessung in DIN 1045-1 für Bauteile aus Konstructionsbeton mit Querkraftbewehrung. // Bauingenieur. 76, 4(2001), pp. 168179 .

[13] Vecchio, F. J.; Collins, M. P. The Modified CompressionField Theory for Reinforced Concrete Elements Subjected to Shear. // ACI Journal. 83, 2(1986), pp. 219-231.

[14] CEB-FIP. Model Code for Concrete Structures: CEB-FIB International Recommendations. Comité Euro-International du Béton, Paris, 1978.

[15] ÖNORM B 1992-1-1: Eurocode 2 - Design of concrete structures - Part 1-1: General rules and rules for buildings National specifications concerning ÖNORM EN 1992-1-1, national comments and national supplements. Austrian Standards Institute, Vienna, 2007.

[16] DIN EN 1992-1-1/NA: National Annex - Nationally determined parameters - Eurocode 2: Design of concrete structures - Part 1-1: General rules and rules for buildings. Normenauschuss Bauwesen (NABau) im DIN, Berlin, 2011.

[17] Marti, P. Basic Tools of Reinforced Concrete Beam Design. // ACI Journal. 82, 1(1985), pp. 45-56.

[18] Bentz, E. C.; Collins, M. P. Development of the 2004 Canadian Standards Association (CSA) A23.3 shear provisions for reinforced concrete. // Canadian Journal of Civil Engineering. 33, 5(2006), pp. 521-534. DOl: 10.1139/106-005

[19] Vecchio, F. J.; Collins, M. P. Predicting the Response of Reinforced Concrete Beams Subjected to Shear Using Modified Compression Field Theory. // ACI Structural Journal. 85, 3(1988), pp. 258-268.

[20] Shrinavas, B. B.; Collins, M. P. Influence of Axial Tension on the Shear Capacity of Reinforced Concrete Members. // ACI Structural Journal. 86, 5(1989), pp. 570-581.

[21] Joint ACI-ASCE Committee 445. ACI 445R-99 (Reapproved 2009): Recent Approaches to Shear Design of Structural Concrete. American Concrete Institute, Farmington Hills, 2009.

[22] Vecchio, F. J.; Collins, M. P.; Aspiotis, J. High-Strength Concrete Elements Subjected to Shear. // ACI Structural Journal. 91, 4(1994), pp. 423-432.

[23] Litzner, H. U. Design of Concrete Structures to ENV 1992 Eurocode 2. // Concrete Structures: Euro-Design Handbook 1994/96 / Weinheim: Vch Verlagsgesellschaft Mbh, 1995. pp. 137-308. 


\section{Authors' addresses}

Davor Grandić, PhD, Associate Professor

Faculty of Civil Engineering, University of Rijeka

Radmile Matejčić 3, 51000 Rijeka, Croatia

E-mail: davor.grandic@gradri.uniri.hr

Paulo Š́ulac, PhD, Assistant

Faculty of Civil Engineering, University of Rijeka

Radmile Matejčić 3, 51000 Rijeka, Croatia

E-mail: paulo.sculac@gradri.uniri.hr

Ivana Štimac Grandić, PhD, Associate Professor Faculty of Civil Engineering, University of Rijeka

Radmile Matejčić 3, 51000 Rijeka, Croatia

E-mail: istimac@gradri.uniri.hr 